\title{
Principal Component Analysis for Sensory Profiling of Rendang from Various Region in West Sumatra
}

\author{
Novizar Nazir", Tuty Anggraini", Lisa Rahayu* \\ \# Laboratory of Sensory and Quality Control, Faculty of Agricultural Technology, Andalas University. Padang, Indonesia. \\ E-mail:nazir_novizar@ae.unand.ac.id
}

* Agroindustrial Technology-Postgraduates Program, Andalas University. Indonesia

\begin{abstract}
Rendang is one of traditional food of Minangkabau society, West Sumatera which has unique flavor and aroma. The characteristic of rendang is the umami taste which is a mixture of salty, sweet and spicy flavor that harmonizes with each other. The main ingredients in the manufacture of rendang are meat, coconut milk, and spices. Spices used in rendang are red chili, red onion, garlic, turmeric, galangal, coriander, lemongrass, ginger, candlenut, bay leaf, turmeric leaves and orange leaves. The use of these spices can improve the aroma and distinctive taste of rendang. The purpose of this study was to identify the sensory characteristics of rendang products from various regions in West Sumatra. The method used to analyze rendang sensory characteristics is Quantitative Descriptive Analysis (QDA) which uses trained panelists on the test. QDA consist of panelist training, Focus Group Discussion (FGD) and sensory testing of rendang products. There are 11 attributes identified by the panelists on rendang are obtained from FGD, they are blackish color and aroma (oil, roasted coconut, umami, aroma of meat and smoke), and taste (sweet, salty, spicy, umami and bitter). The results of QDA test were analyzed using Principal Component Analysis (PCA). The PCA identified four major components that accounted for $\mathbf{9 9 . 3 \%}$ of the variation of sensory data. Sensory profiling shows the correlation between each attribute and the sample of rendang indicating that the rendang is spread over four quadrants. Rendang from Bukittinggi is found in the first quadrant and characterized by the aroma of fishy, the taste of salt and sweet. Rendang from Pariaman, Sawahlunto, and Tanah Datar / Batusangkar are found in the second quadrant characterized by umami aroma, spicy flavors, umami taste and aroma of the oil. Rendang from Padang is in the third quadrant and characterized by the aroma of roasted coconut and black color. Rendang from Payakumbuh contained in the fourth quadrant characterized by the aroma of smoke and bitter taste. Based on the evaluation of sensory characteristics performed using PCA, it can be concluded that the new sensory characteristics (the result of a reduction of eleven sensory attributes analyzed) on rendang products in various areas in West Sumatra can be distinguished by four attributes: aroma, cooking time, spices and flavors. This is the first systematic study on profiling of sensory attributes of rending using a standard sensory method.
\end{abstract}

Keywords — rendang; profiling; sensory; quantitative descriptive analysis (QDA); principal component analysis (PCA).

\section{INTRODUCTION}

Rendang is one of traditional food of Minangkabau society, West Sumatera. It has a distinctive taste, because it uses various kinds of spices. The cooking process takes about 6-7 hours at $80-90{ }^{\circ} \mathrm{C}$, until the meat turns its color to dark or black and produces a distinctive aroma and flavor [1]. As product quality drives consumer acceptance and demand, the ability to measure the sensory attributes of high-quality products is required for product development and production that meet the expectation of consumer. [2] Sensory analysis is the process, measurement, analysis, and interpretation of all product attribute through the five human senses; sense of sight, smell, tasting, touch, and hearing and using measurements that are quantitative or qualitative [3].
Excavation of attribute sensory of rendang can be obtained through Quantitative Descriptive Analysis (QDA). This analysis is one of the most potent, sophisticated and most widely used tools in sensory science, which provides a complete picture of the sensory characteristics of food products [4]. This technique has been used worldwide to characterize the sensory attributes of some food products [5].The QDA method is performed on the ability of the panelist to express the product in words using a trusted way [3]. The QDA principle is based on the ability to train the panelist to measure the specific attributes of a product reproducibly to produce a comprehensive quantitative product description that fits the statistical analysis. In a QDA approach, panelists recruited from the general public work together in a focus group to identify key product attributes and appropriate intensity scales specific to a product. This 
group of panelists is then trained to recognize and score product attributes reliably. As panelists generate the attribute terms, the resulting descriptions are meaningful to consumers, and thus, analyses provide information amenable to modeling predictions of consumer acceptability. QDA results can be analyzed statistically and then represented graphically [2].

Descriptive techniques are frequently used in product development to measure how close a new introduction is to the target or to assess the suitability of prototype products [6]. In consumer sensory analysis the investigator is interested in whether the consumer likes the product, prefers it to another product, or finds the product acceptable based on its sensory characteristics [6]. Preference mapping is a sensory tool to accomplish integration between consumer reactions and descriptive data [7]

By relating consumer data with descriptive data, the researcher can discover the relationships between product attributes and the ultimate bottom line, consumer acceptance [8]. One of the more recent topics in product research is the notion of "drivers of liking", or the nature of sensory features that drive acceptance [9]. Sensory properties is the most critical factors on consumer liking and preference; thus, it is essential to determine factors affecting the product attributes, acceptance and preference especially for foods and drinks [10]. Furthermore, preferences play a central role in determining food selection and diet quality

Information obtained through QDA was analyzed using the Principal Component Analysis (PCA) method. This method is a multivariate analytical statistical technique that is widely used and can be applied to the QDA data to reduce the set of dependent variables (ie, attributes) to a smaller set of underlying variables (called factors) based on the correlation pattern among the original variables [11]. The resulting data can then be applied as follows: profile of specific product characteristics; compare and differentiate similar products based on attributes that are important to the consumer; and alter product characteristics with the aim of increasing market share for a specific set of products [2].

Based on the geographical location in West Sumatra, rendang is divided into two main group, namely the rendang which is located in the highlands (darek) and the rendang which is found in the lowlands (coastal). Darek area is the old areas where the origin of the Minangkabau Kingdom located. Darek consists of Tanah Datar, Agam, Limapuluh Kota, Payakumbuh, Padang Panjang, and Bukittinggi. While the Coastal areas include Pariaman City, Padang Pariaman District, Padang City, Pesisir Selatan and Pasaman Regency. Rendang from darek, contains more simple spices and simple cooking technique when compared with coastal rendang. Differences in cooking techniques and spices used results in variations in taste and aroma of rendang. According to the literature review, it is evident that no systematic study has been reported so far on the profiling of sensory attributes of Rendang using standard sensory methods. Therefore it is necessary to conduct this study. The objective of this study were to: 1) assess the utility of QDA for evaluating rendang from different parts of West Sumatra, 2) identify the principal components (PC) contributing to the sensory evaluation of rendang from various parts of West Sumatra., and 3 ) develop a model for predicting overall rendang quality.

\section{MATERIALS AND METHOD}

\section{A. Materials}

The materials used in this research are rendang from 6 (six) regencies / cities in West Sumatra (Indonesia) (Fig.1), namely Padang, Payakumbuh, Bukittinggi, Tanah Datar, Sawahlunto and Pariaman (Fig. 2). Standard flavor solutions use commercial salt $(\mathrm{NaCl})$, monosodium glutamate (MSG), citric acid (p.a), sugar, caffeine and mineral water.

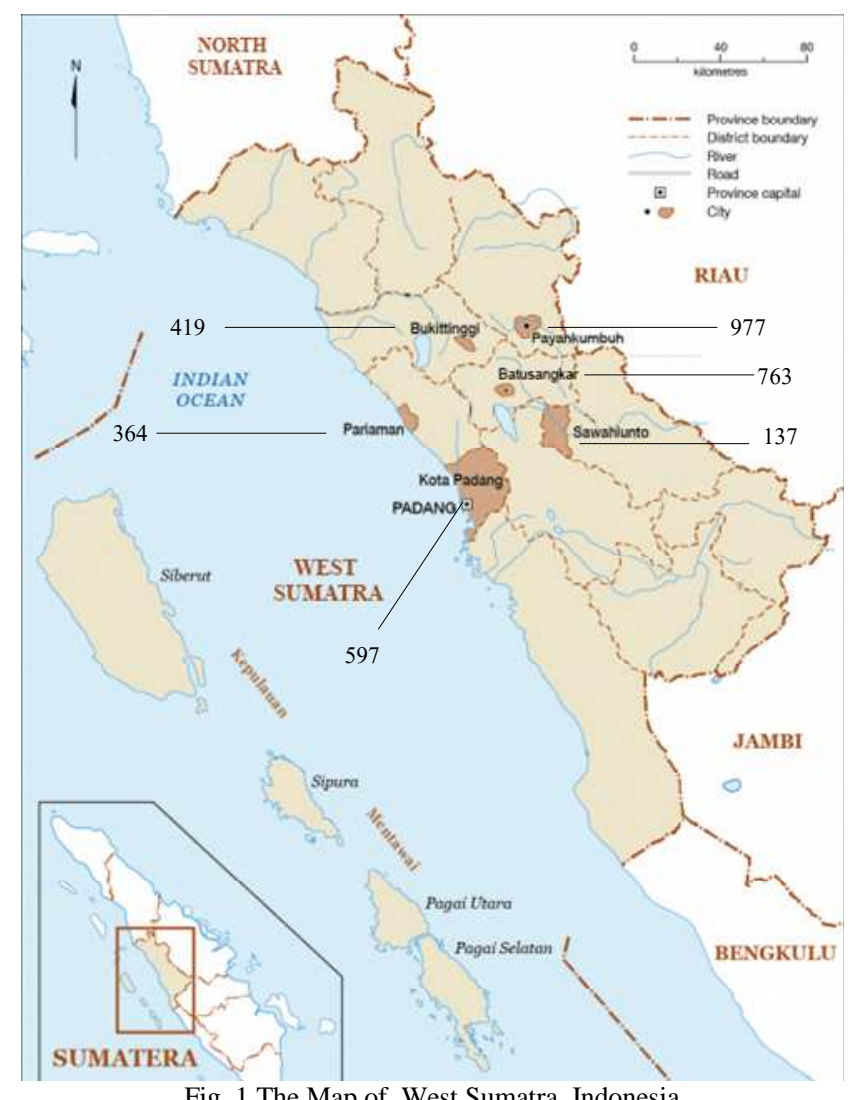

Fig. 1 The Map of West Sumatra, Indonesia
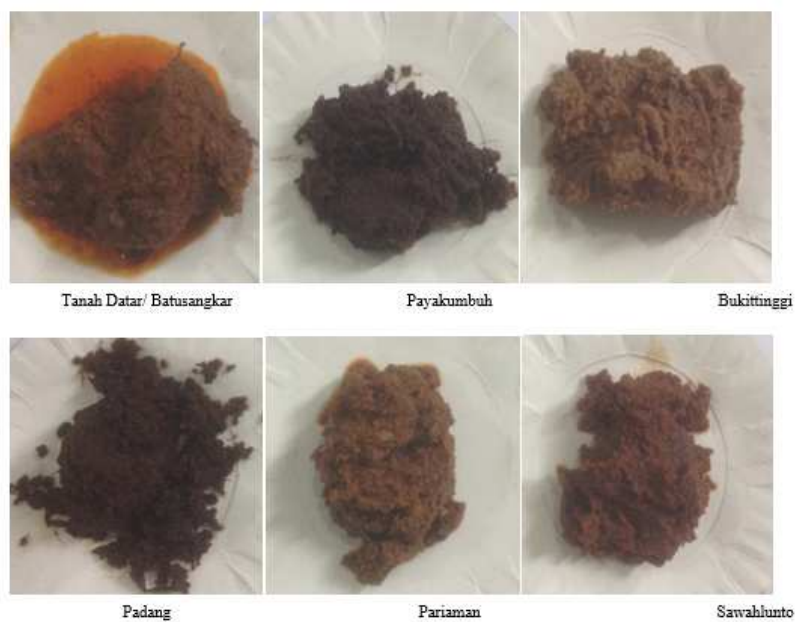

Fig. 2. Sample of Rendang from 6 (six) regencies / cities in West Sumatra 


\section{B. Panelist Selection}

The first step in this research was panelist selection. Panelist selection was performed to obtain panelist candidate to be trained to be a trained panelist who will then be included to perform tests on the sensory attribute specified on rendang. The panelist selection process consists of prescreening, acuity test and personal interview. The selection process was carried out for 3 weeks. Pre-screening was done through questionnaires containing questions that include health, time, food habits and knowledge of spices. Prescreening test was attended by 100 students candidates panelists.

The basic taste and aroma identification test was performed by 20 candidate panelists consisting of 11 women and 9 men. The basic taste identification test is done using some basic flavors ie. sweet, sour, salty, bitter, umami and spicy. The aroma identified is the aroma of smoke and the aroma of oil. From 20 panelists who performed the basic taste and aroma identification test, 18 people were subsequently followed the triangle test of taste. The triangle test using the solution of sugar, citric acid, salt, MSG, chilli and coffee. Testing was done several times for 3 days. From the triangle test, there were 14 trained panelists who will be included in the next stage. The next stage is personal interview. All panelists (14 people) were interviewed to see the ability and commitment to follow the next stage. The standard solution used in the taste consistency test refers to standard solutions made by Pratama [12] can be seen in Table I.

TABLE I

STANDARD SOLUTION WHICH Is USED IN CONSISTENCY TEST

\begin{tabular}{|c|c|c|}
\hline Taste & Standard & Concentration (\%) \\
\hline Salty & $\mathrm{NaCl}$ & 0.2050 \\
\cline { 3 - 3 } & & 0.5355 \\
\cline { 3 - 3 } & & 0.8660 \\
\hline \multirow{2}{*}{ Umami } & \multirow{2}{*}{ MSG } & 0.0240 \\
\cline { 3 - 3 } & & 0.0570 \\
\hline \multirow{2}{*}{ Sweet } & \multirow{2}{*}{ Sucrose } & 0.0900 \\
\cline { 3 - 3 } & & 0.6000 \\
\hline Hot & \multirow{2}{*}{ Chilli } & 1.2000 \\
\cline { 3 - 3 } & & 1.8000 \\
\cline { 3 - 3 } & & 0.2050 \\
\hline
\end{tabular}

\section{Quantitative Descriptive Analysis (QDA)}

Sensory testing using quantitative description analysis method is carried out by assessing the intensity of the attribute of color, aroma and taste of rendang from various areas. The assessment was conducted by 14 trained panelists. The training was conducted with basic taste recognition test, triangle test and aroma consistency test and basic taste. Qualitative methods are performed with focus group discussion techniques and quantitative methods using QDA. The panelists assessed the sensory attribute of rendang using a $15 \mathrm{~cm}$ line scale with an intensity score of 0 to 60 . The attributes of color were blackish, the aroma of oil, coconut, umami, aroma of meat and smoke while the taste attribute tested is sweetness, salty, spicy, umami and bitterness. QDA test results are analyzed and reported in graphical in spider web form using Microsoft Office Excel 2007.

\section{Principal Component Analysis (PCA)}

Principal Component Analysis (PCA) is the statistical technique used to recognize the smallest number of latent variables, called "principal components," which determines the greatest amount of observed variability. Generally it is possible to determine as much as $75 \%$ to $90 \%$ of the total variability in a data set consisting of 25 to 30 variables with as few as 2 to 3 principal components [13]. PCA basically analyze the correlation matrix of the variables. PCA used to analyze the correlation structure of a group of multivariate observations and provides the axis along which the maximum variability in the data occurs. The axis along which maximum vari ability in the data occurs called the first principal component. The second principal component is the axis along which the greatest amount of remaining variability occurs, subjected in such a manner that the axes must be perpendicular (at right angles) to each other (i.e. orthogonal or uncorrelated). For the description among the original variables, PCA can be used to display the relative "locations" of the samples. PCA provides a way to summarize data collected on a large number of variables in fewer dimensions. It is tempting to ask if it is necessary to continue to evaluate all of the original variables as opposed to only a few "representative" ones. The number of variables that are studied should not be reduced based on PCA results [14]. Multivariates Statistical Analysis of Principal Component Analysis (PCA) was carried out using Minitab 17.

\section{RESULT AND DISCUSSION}

\section{A. Quantitative Descriptive Analysis (QDA)}

Sensory analysis used in this study is the QDA method. This method uses trained panelists to identify rendang samples from different regions of West Sumatra. In the first stage a trained panelist will perform a sensory test of attribute of color, aroma and taste on all rendang samples. Qualitative analysis was conducted using FGD (Focus Group Discussion) method and quantitatively using QDA (Quantitative Descriptive Analysis). Atttribute analysis of color, aroma and taste of rendang samples was done qualitatively using FGD method performed by 14 panelists and one moderator. The results of the discussion on the color, aroma and taste of rendang are found in Table 2.

After the qualitative analysis was conducted with FGD method, the atttributes of color, aroma and taste were obtained to be used in quantitative analysis. The quantitative analysis method used in the evaluation of the sixth characteristic sensory characteristic of rendang is the QDA method. There are 14 panelists who follow this test. The sensory attributes tested are black, aroma of oil, roasted coconut aroma, umami aroma, fishy aroma, smoky aroma, sweet taste, salty taste, spicy taste, umami taste and bitter taste.

The test was done by assessing the intensity of color, aroma and taste of each rendang sample using a $15 \mathrm{~cm}$ length line scale, on a scale of 0 to 60. All QDA values are 
displayed in Table which is then translated into the spider web graph. Spider web graph is a traditional method that is still used to interpret QDA results, this is because by using the spider web can see all the sensory attributes profile and can be compared between the one attribute profile with the other atttribute profile [15].

TABLE II.

Qualitative ANALYsis Results OF SENSORIC ATtRIBUTES BASED ON FGD

\begin{tabular}{|l|l|l|}
\hline No & Atttribute & Description \\
\hline 1 & Black & $\begin{array}{l}\text { Typical color of rendang } \\
\text { (brownish to blackish) }\end{array}$ \\
\hline 2 & Aroma of oil & Aroma of oily food \\
\hline 3 & $\begin{array}{l}\text { Aroma of roasted } \\
\text { coconut }\end{array}$ & Aroma of roasted coconut \\
\hline 4 & Aroma of umami & Aroma of blend of spices \\
\hline 5 & Aroma of fishy & Aroma of meat \\
\hline 6 & Aroma of smoke & $\begin{array}{l}\text { The smell of wood smoke from } \\
\text { the fireplace }\end{array}$ \\
\hline 7 & Sweet & $\begin{array}{l}\text { Taste in the tongue associated } \\
\text { with sugar }\end{array}$ \\
\hline 8 & Salty & $\begin{array}{l}\text { Taste in the tongue associated } \\
\text { with salt }\end{array}$ \\
\hline 9 & Hot & $\begin{array}{l}\text { Taste in the tongue associated } \\
\text { with chili }\end{array}$ \\
\hline 10 & Umami & $\begin{array}{l}\text { Taste generated from MSG } \\
\text { at the base of the tongue }\end{array}$ \\
\hline 11 & Bitter &
\end{tabular}

\section{1) The Attribute of Color}

Table III shows the average QDA score of 6 rendang samples. This data is the result of an average of 14 panelists from QDA testing with 3 replications using the intensity scale of 0 (lowest) to 60 (highest). This average value is presented in the form of spider web graph (Fig.3). Based on the results of the analysis contained in the graph, it can be seen the color value difference of each rendang.

TABLE III

QDA TEST Results OF COLOR ATtTRIBUte

\begin{tabular}{|c|c|}
\hline Sample origin & QDA value of color \\
\hline Padang & 38.81 \\
\hline Payakumbuh & 39.40 \\
\hline Bukittinggi & 13.79 \\
\hline Tanah Datar & 18.43 \\
\hline Sawahlunto & 18.24 \\
\hline Pariaman & 1793 \\
\hline
\end{tabular}

The color assessment on rendang used the range of values 0-60 where the range 0-30 describes the brownish yellow color while the value $31-60$ describes the color of the blackish rendang. The higher the value describes the black color of the rendang. Based on spider web graph (Fig. 3). Rendang from Payakumbuh described has a color that is more black than rendang from other areas.

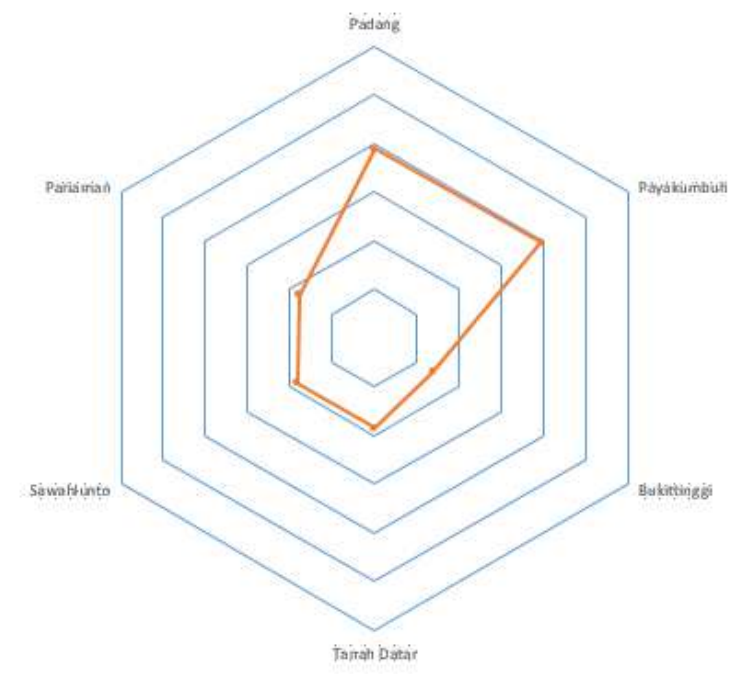

Fig. 3. The spider web graph of the attribute of Color

The existence of brownish color to blackish on rendang is a result of chemical reactions that occur in rendang, the maillard reaction. The maillard reaction is a non-enzymatic browning reaction involving reducing sugars and amino acids. This reaction causes the formation of yellow to brown (melanoidin) in the product. Lund and Ray [16] suggest that maillard reactions can cause changes in food color, organoleptic properties, protein function, and protein digestibility.

The process of rendang production requires a high heat and a long time, so it is suspected that this resulted in a maillard reaction. This is a reaction between carbohydrates and amino groups naturally requires no additional chemicals and will take place under conditions of temperature, time, $\mathrm{pH}$ and controlled humidity [17].

\section{2) Atribut aroma}

Based on QDA test conducted by 14 trained panelist, the intensity value of each rendang was obtained (Table 4).

TABLE IV

QDA VALUE OF AROMA OF RENDANG FROM VARIOUS REGION

\begin{tabular}{|c|c|c|c|c|c|}
\hline $\begin{array}{c}\text { Sample } \\
\text { origin }\end{array}$ & Oil & $\begin{array}{c}\text { Roasted } \\
\text { coconut }\end{array}$ & Umami & Fishy & Smoke \\
\hline Padang & 28.93 & 38.88 & 33.74 & 7.762 & 17.86 \\
\hline Payakumbuh & 31.43 & 36.36 & 26.29 & 12.36 & 21.38 \\
\hline Bukittinggi & 22.79 & 23.86 & 27.69 & 27.64 & 11.21 \\
\hline Tanah Datar & 36.88 & 26.38 & 41.05 & 15.38 & 9.905 \\
\hline Sawahlunto & 27.9 & 36.26 & 38.5 & 12.95 & 11.5 \\
\hline Pariaman & 35.98 & 27.26 & 38.62 & 15.57 & 14.64 \\
\hline
\end{tabular}

The results of the aroma description in QDA's spider web testing chart (Fig.4) show that rendang from Tanah Datar has a higher aroma of oil and umami aroma than other rendang. Rendang from Padang has a higher intensity of roasted coconut scent than other rendang. Further rendang from Payakumbuh has a higher smoke intensity and rendang Bukittinggi has a higher intensity of meat aroma than other rendang. 


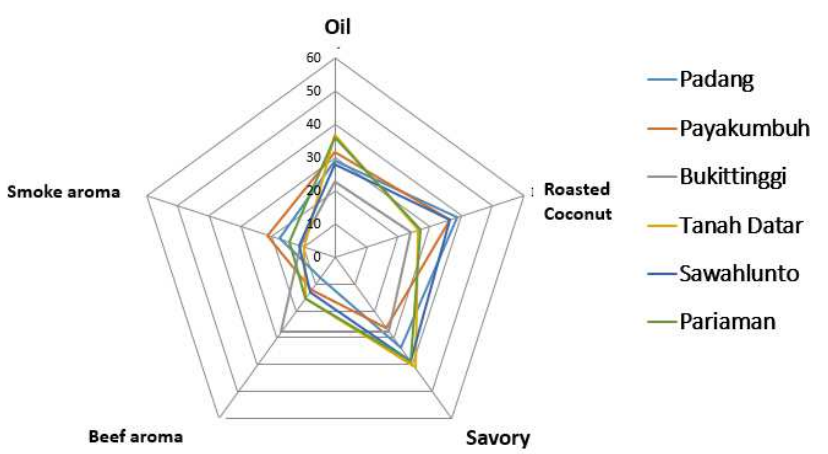

Fig.4. Spider web graph of the attribute of aroma

Aroma can be recognized when it is in steam-shaped and the component molecules touch the cilia of the olfactory cells and are passed on to the brain in the form of electrical impulses by the ends of the olfactory nerves. In general, the smell received by the nose and the brain is more of a variety of herbs or mixtures of four major odors, fragrant, sour, rancid and charred [18].

Aroma is one of the characteristic of the food produced by the use of spices. Spices that are used are the leaves (fresh and dried), stems, tubers, rhizomes, seeds or fruit as a seasoning food. The compound that gives Characteristic aroma and taste in rendang comes from the spices used in the manufacturing process. Antara and Wartini [19] states that spices can affect the smell, color and taste of food and sometimes can mask unwanted aromas. The aroma of a food can also be affected by the maillard reaction that occurs in food, causing a distinctive aroma to the food. The maillard reaction between sugar and amino compounds does not require very high temperatures compared to the caramelization of sugars and protein pyrolysis so as to easily form aromas at cooking temperatures [20]. In the rendang sensory test, the aroma that appears and agreed by the panelists is the aroma of oil, coconut roaster, umami, fishy and smoke.

\section{3) The Attribute of Taste}

Based on QDA test conducted by 14 trained panelists, the intensity value of the taste attribute of rendang as shown in Table V.

TABLE V

QDA VALUE OF TASTE OF RENDANG FROM VARIOUS REGION

\begin{tabular}{|c|c|c|c|c|c|}
\hline Sample origin & Sweet & Salty & Hot & $\begin{array}{c}\text { Uma } \\
\text { mi }\end{array}$ & Bitter \\
\hline Padang & 25.11 & 29.95 & 24.04 & 29.23 & 18.78 \\
\hline Payakumbuh & 16.42 & 31.85 & 19.33 & 21.38 & 30.35 \\
\hline Bukittinggi & 30.57 & 35.19 & 22.54 & 27.16 & 6.83 \\
\hline Tanah Datar & 24.21 & 37.19 & 33.40 & 33.95 & 8.61 \\
\hline Sawah Lunto & 28.54 & 34.07 & 29.28 & 35.80 & 8.92 \\
\hline Pariaman & 30.45 & 28.54 & 24.73 & 34.78 & 5.57 \\
\hline
\end{tabular}

This average value is presented as a spider web (Fig.5). Based on the results of the analysis contained in the graph, it can be seen the difference of each product rendang them.

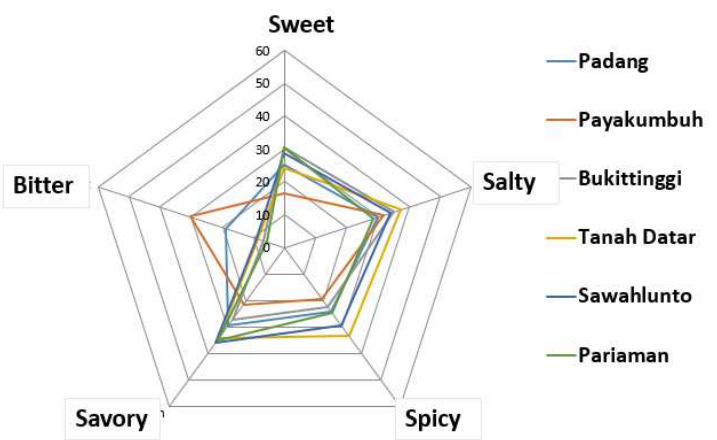

Fig. 5. Spider web graph of taste of rendang

\section{B. Principal Component Analysis (PCA)}

According to Sartono, Afendi, Syafitri, Sumertajaya and Angraeni [21], there are three main methods that can be used in determining the number of major components. The first method is based on the cumulative proportion of total unexplained diversity, the second method using Eigen Value (Table VI) and the third method of using the scree plot / loading plot graph (Fig.6).

TABLE VI

The Eigen Value With Percentage And Cumulative Diversity OF ELEVEN ATTTRIBUTES OF RENDANG

\begin{tabular}{|c|c|c|c|}
\hline Component & $\begin{array}{c}\text { Eigen } \\
\text { Value }\end{array}$ & Percentage & Commulative \\
\hline $\mathrm{X} 1$ & 5.9455 & 0.541 & 0.541 \\
\hline $\mathrm{X} 2$ & 2.7606 & 0.251 & 0.791 \\
\hline $\mathrm{X} 3$ & 1.3233 & 0.120 & 0.912 \\
\hline $\mathrm{X} 4$ & 0.8936 & 0.081 & 0.993 \\
\hline $\mathrm{X} 5$ & 0.0769 & 0.007 & 1.000 \\
\hline $\mathrm{X} 6$ & 0.0000 & 0.000 & 1.000 \\
\hline $\mathrm{X} 7$ & 0.0000 & 0.000 & 1.000 \\
\hline $\mathrm{X} 8$ & -0.0000 & -0.000 & 1.000 \\
\hline $\mathrm{X} 9$ & -0.0000 & -0.000 & 1.000 \\
\hline $\mathrm{X} 10$ & -0.0000 & -0.000 & 1.000 \\
\hline $\mathrm{X} 11$ & -0.0000 & -0.000 & 1.000 \\
\hline
\end{tabular}

Based on the scree plot graph, it can be seen that at $\mathrm{k}=4$ the image looks very steep scree plot on the left but ramps on the right. So the four main components used are sufficient and can cover all variables, namely Z1, Z2, Z3, Z4, Z5, Z6, Z7, Z8, Z9, Z10 and Z11.

Based on the these three methods, there are four main proncipal components (PC1, PC2, PC3, PC4) which are used to translate the data because it can explain $99.3 \%$ of the total diversity in the sensory attribute data. The contribution of each is to use 1 main component (PC1) then the data diversity proportion is $54.1 \%$, using 2 main components (PC1, PC2) the proportion of diversity is $79.1 \%$, using 3 main components (PC1, PC2 and PC3) the proportion of diversity is $91.2 \%$ and using 4 main components (PC1-PC4) then the proportion of diversity is $99.3 \%$ close to $100 \%$. 


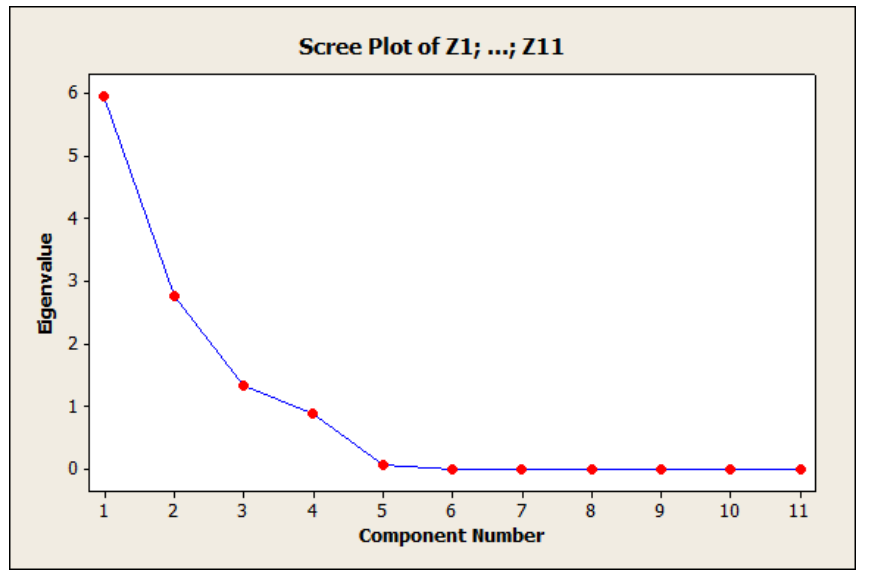

Fig. 6. Screen plot graph

Based on the four main components, proposed by taking the highest absolute values and the characteristic vector values (shown positively or negatively in Table VII), the the value generated from the processing using PCA is shown in graphical form. The graph shows the location points of each sample of rendang around the sensory atttribute of color (brown, black), aroma (oil, roasted coconut, umami, fishy, smoked) and flavor (sweet, salty, spicy, umami, bitter) which becomes characteristic of rendang samples (Fig.7).

TABLE VII

VECTOR VALUES OF THE RELATIONSHIP BETWEEN EACH VARIABLE WITH THE MAIN COMPONENT

\begin{tabular}{|c|c|c|c|c|}
\hline Variable & $\begin{array}{c}\text { PC1 } \\
\mathbf{( 5 4 . 1 \% )}\end{array}$ & $\begin{array}{c}\text { PC2 } \\
\mathbf{( 7 9 . 1 \% )}\end{array}$ & $\begin{array}{c}\text { PC3 } \\
\mathbf{( 9 1 . 2 \% )}\end{array}$ & $\begin{array}{c}\text { PC4 } \\
\mathbf{( 9 9 . 3 \% )}\end{array}$ \\
\hline Z1 & 0.041 & -0.444 & -0.156 & 0.680 \\
\hline Z2 & -0.287 & -0.271 & 0.091 & -0.566 \\
\hline Z3 & 0.273 & -0.449 & 0.023 & 0.005 \\
\hline Z4 & 0.204 & 0.508 & -0.049 & 0.200 \\
\hline Z5 & -0.396 & -0.054 & 0.152 & 0.179 \\
\hline Z6 & 0.319 & 0.112 & 0.501 & -0.148 \\
\hline Z7 & 0.195 & 0.157 & -0.700 & -0.254 \\
\hline Z8 & 0.303 & -0.319 & -0.325 & -0.181 \\
\hline Z9 & 0.328 & -0.320 & 0.202 & -0.138 \\
\hline Z10 & -0.394 & -0.032 & -0.229 & -0.011 \\
\hline Z11 & -0.385 & -0.157 & -0.037 & -0.082 \\
\hline
\end{tabular}

Bi-plot graph can provide information about the relationship between variables, relative resemblance between objects of observation, relative position between observation objects and variables. The distance between samples and variables shows the relationship between the sample and the variable. The relationship between two sample points can be seen by comparing the distance with the points of the variable [3]. Based on PCA analysis (PC1-PC4 99.3\%) showed that rendang samples were grouped into their respective quadrants. There are those that occupy the same quadrant and there are different ones. This shows that each rendang has its own characteristic.

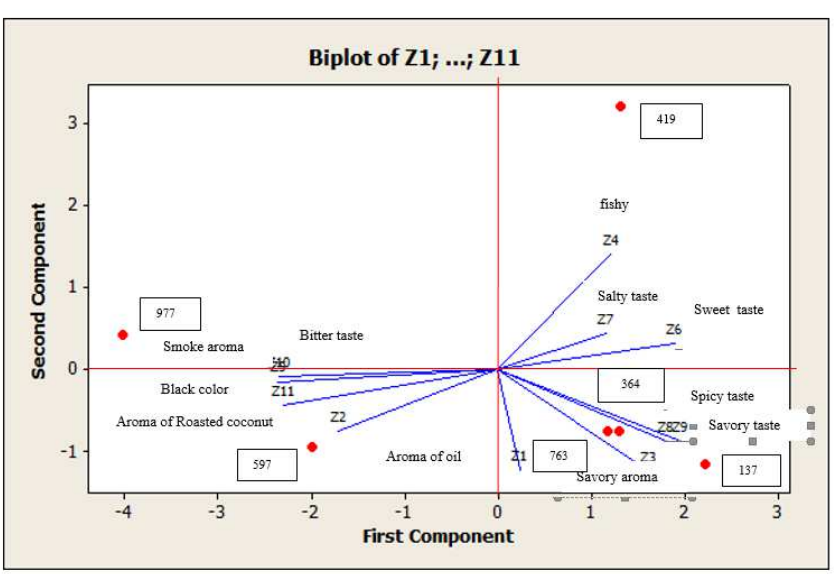

Fig. 7. The bi-plot graph explains the relationship between the rendang sample and the sensory attribute of the aroma and the overall taste

Description:

\begin{tabular}{|c|c|c|}
\hline & : Aroma of oil & 597 : Padang \\
\hline $\mathrm{Z} 2$ & : Aroma of roasted coconut & 977 : Payakumbuh \\
\hline $\mathrm{Z3}$ & : Aroma of umami & 419 : Bukittinggi \\
\hline $\mathrm{Z4}$ & : Aroma of fishy & 763: Tanah Datar/Batusangkar \\
\hline $\mathrm{Z5}$ & : Aroma of smoke & 137 : Sawahlunto \\
\hline Z6 & : Sweet taste & 364 : Pariaman \\
\hline $\mathrm{Z7}$ & : Salty taste & \\
\hline $\mathrm{Z8}$ & : Hot taste & \\
\hline & : Umami taste & \\
\hline & : Bitter taste & \\
\hline & Black color & \\
\hline
\end{tabular}

Rendang from Bukittinggi (419) is on the far right side of the first quadrant and is characterized by the attribute of a fishy aroma, saltiness and sweetness. The QDA results in Table IV, the fishy aroma, provide a description of the same results as PCA graphs. The intensity of the fishy aroma based on the description test by panelists was detected the highest on samples from Bukittinggi (419) when compared with other rendang samples with a value of 27.64. Salty and sweet taste also become characteristic of rendang from Bukittinggi. This result is similar to QDA result that is salty taste with value 35,19 and sweet taste with value 30,57 . The intensity of saltiness based on the description test by the panelists was detected in the second sequence after the rendang from Tanah Datar/Batusangkar of 763 (37.19) sample with the value of 35.19. Salty taste is the flavor generated from the use of inorganic salts, namely $\mathrm{NaCl}$. The sweetness intensity based on the description test by panelists was detected highest than other rendang. The presence of sweetness caused by the sugar content contained in the meat and the addition of spices that produce sweetness.

Rendang from Pariaman (364) is present in the second quadrant and characterized by the attribute of umami aroma, spicy flavor and taste. The QDA results in Table IV, the umami aroma, provide a description of the same results as the PCA graphs. The intensity of the umami aroma based on the description test by the panelists was detected to have the second highest value of 38.61 after the sample from Batusangkar (763) (41.04). Spicy and umami taste also become Characteristic of rendang Pariaman. This result is 
similar to QDA result that is spicy flavor with value 24,73 and umami taste with value 34.78 .

Rendang from Sawahlunto (137) is present in the second quadrant and characterized by Atttribute umami aroma and umami flavors. The QDA results in Table IV, the umami aroma, provide a description of the same results as PCA graphs. The intensity of the umami aroma based on the description test by the panelists was detected to have a value in the third sequence that is 38.5 after the sample 763 (41.04) and 364 (38.61). Umami taste is also a Characteristic of rendang Sawahlunto. This result is also equal to the results of QDA that is tasty has the highest value when compared with other rendang with a value of 35.80 .

Rendang from Batusangkar (763) is also present in the second quadrant characterized by Atttribute aroma of oil, umami aroma and spicy flavor. The QDA results in Table IV, oil fragrance, umami scent and spicy flavor provide a description of the same results as PCA graphs. The intensity of the aroma of oil, the umami aroma and the spicy flavors based on the description test by the panelists were detected at the highest in sample 763 (Batusangkar) when compared with other rendang samples. Aroma of oil 36.88; umami aroma of 41.04 and spicy flavors of 33.40.

Rendang from Padang (597) is located in the third quadrant characterized by the smell of coconut roasting and black color. The QDA results in Table IV, the roasted coconut and black hues give descriptions of the same results as PCA graphs. The intensity of coconut roasting aroma based on the description test by panelists was detected highest on sample 597 (Padang) when compared with other rendang samples. For the intensity of the resulting black color, rendang from Padang comes in second after rendang 977 (39.40) with a value of 38.80. The high intensity value of black color is influenced by the time used in the manufacture and processing of rendang.

Rendang from Payakumbuh (977) is located in the fourth quadrant characterized by the smell of smoke and bitterness. The QDA results in Table IV, the smell of smoke and bitterness provide a description of the same results as PCA graphs. The intensity of smoke and bitter flavor based on the description test by panelists was detected highest in 977 samples (Payakumbuh) when compared with other rendang samples, with smoke scent value of 21.38 and bitter taste with value of 30.35 . The high smell of smoke and bitterness is generated from the manufacture or processing of rendang is too long.

From bi-plot graph, there are three samples of rendang located in the same quadrant that is 763,137 and 364 . This means that the three types of rendang has a somewhat similar karaktiristik that is characterized by Atttribute spicy flavors, taste of umami umami aroma and aroma oil. This is likely caused by the use of materials in the manufacture of rendang in the same amount.

Based on the results of the analysis using PCA, of the eleven attributes of rendang (black color, aroma of oil, aroma of roasted coconut, aroma of umami, aroma of fishy, aroma of smoke, sweet taste, salty taste, spicy taste, umami taste and bitter taste) can be grouped or reduced to 4 new characteristics (Table VIII).

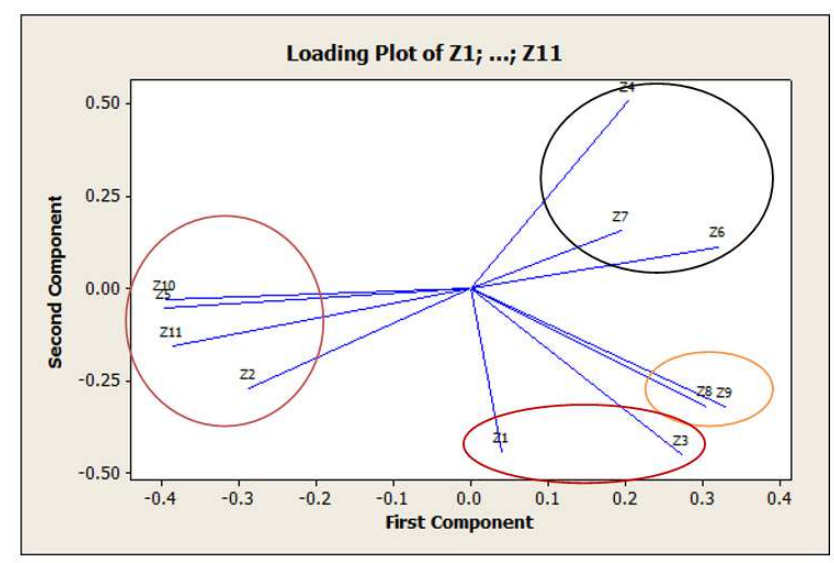

Fig. 8. Loading Factor

TABLE VIII

NEW CHARACTERISTIC BASED ON REDUCTION OF ALL ATTRIBUTES IN PCA

\begin{tabular}{|l|l|l|}
\hline New Characteristic & Attribute & \\
\hline \multirow{4}{*}{ Aroma } & Aroma of oil & $\mathrm{Z} 1$ \\
\cline { 2 - 3 } & Aroma of umami & $\mathrm{Z} 3$ \\
\hline \multirow{5}{*}{ Spices } & $\begin{array}{l}\text { Aroma of roasted } \\
\text { coconut }\end{array}$ & $\mathrm{Z} 2$ \\
\cline { 2 - 3 } & Aroma of smoked & $\mathrm{Z} 5$ \\
\cline { 2 - 3 } & Bitter tatste & $\mathrm{Z10}$ \\
\cline { 2 - 3 } & Black color & $\mathrm{Z11}$ \\
\hline \multirow{5}{*}{ Taste } & Aroma of fishy & $\mathrm{Z} 4$ \\
\cline { 2 - 3 } & Sweet taste & $\mathrm{Z6}$ \\
\cline { 2 - 3 } & Salty taste & $\mathrm{Z7}$ \\
\hline & Hot taste & $\mathrm{Z} 9$ \\
\cline { 2 - 3 } & Umami taste & \\
\hline
\end{tabular}

There are four new characteristic of rendang namely aroma, cooking time, spices and flavor. (Table VIII). These four new characteristics are the result of the reduction of the eleven attributes used in the identification of characteristic rendang in various regions. Thus, then the fourth Characteristic (aroma, cooking time, spices and flavor) is what will be the differentiator of rendang in each regency / city in West Sumatra.

\section{CONCLUSIONS}

Based on research conducted, it can be concluded that: [1]. The process of rendang production in various areas in West Sumatra in general has a similar way and use the same material, while the difference is only found in the spices / additional herb used; [2]. The descriptive evaluation of the QDA method of the six sample of rendang (Padang, Payakumbuh, Bukittinggi, Tanah Datar, Pariaman, Sawahlunto) using a trained panelist indicates that each rendang has a certain intensity of sensory attributes that gives the rendang characteristic of each region. Rendang from Padang has more dominant intensity of roasted coconut aroma (38.88).; rendang from Payakumbuh has the dominant intensity of black color (39.40), smoked aroma (21.38) and bitter taste (30.35); rendang from Bukittinggi has the dominant intensity of fishy aroma (27.64) and sweet taste (30.57); rendang fromTanah Datar or Batusangkar has dominat intensity of oil aroma (36.88), umami aroma (41.04), salty taste (37.11) and spicy taste (33.40). Rendang from Sawahlunto has the dominant intensity of the umami 
taste attribute $(35,80)$. While rendang from Pariaman has the same average intensity among all sensory attributes detected by panelists; [3]. Rendang spread over four quadrants. Rendang from Bukittinggi is in the first quadrant and characterized by the aroma of fishy, salty and sweet taste. Rendang from Pariaman, Sawahlunto and Tanah Datar / Batusangkar are found in the second quadrant characterized by umami aroma, spicy flavors, umami taste and aroma of oil. Rendang from Padang is in the third quadrant and characterized by the aroma of roasted coconut and black color. Rendang from Payakumbuh contained in the fourth quadrant and characterized by the aroma of smoke and bitter taste [4]. Based on the reduction of eleven sensory attributes by PCA, there are new sensory characteristics of rendang of West Sumatra can be distinguished by a group of attributes: the aroma, cooking time, spices ingredient and flavors.

\section{ACKNOWLEDGMENT}

The authors would like to thank the Andalas University for providing the funding support through the Grants No: 01G/PL/DF-DIPA/Fateta-2017.

\section{REFERENCES}

[1] Rini, Azima F, Sayuti K dan Novelina. 2016. The evaluasion of Nutrional Value of Rendang Minagkabau.Agriculture And Agricultural Science Procedia 9 (2016) 335-341.

[2] K. W. Chapman, H. T. Lawless, and K. J. Boor. 2001 Quantitative Descriptive Analysis and Principal Component Analysis for Sensory Characterization of Ultrapasteurized Milk. J. Dairy Sci. 84:12-20.].

[3] Setyaningsih D, Apriyantono A, Sari MP.2010. Analisis Sensori Untuk Industri Pangan dan Agro. Bogor; IPB Press.180 p.

[4] Paula Varela Gastón Ares. Food Research International 48 (2012) 893-908. Sensory profiling, the blurred line between sensory and consumer science. A review of novel methods for product characterization.

[5] Paul Mukhopadhyay, S., Saliba, A.J., Carr, B.T., Blanchard, C.L., Wood, J.A., Prenzler, P.D., Sensory profiling and preference mapping of Australian puffed desi chickpeas, LWT - Food Science and Technology (2017), doi: 10.1016/j.lwt.2017.10.040]

[6] Lawless, H. T., \& Heymann, H. (1999). Sensory evaluation of foodprinciples and practices. Gaithersburg, Maryland: Aspen publishers Inc.
[7] Geel, L., Kinnear, M., \& de Kock, H. L. (2005). Relating consumer preferences to sensory attributes of instant coffee. Food Quality and Preference, 16, 237-244.

[8] Meilgaard, M., Civille, G.V. dan Carr, B.T. 1999. Sensory Evaluation Techniques, Third edition. CRC Press LLC, Florida.

[9] Moskowitz, H., Gofman, A., \& Beckley, J. (2006). Using high-level consumer-research methods to create a tool-driven guidebook and database for product development and marketing. Journal of Sensory Studies, 21, 54-100

[10] T. Pohjanheimo. 2010. Sensory And Non-Sensory Factors Behind The Liking And Choice Of Healthy Food Products Functional Foods Forum. Department Of Biochemistry And Food Chemistry University Of Turku. Finland. 90 p.

[11] Jolliffe IT. 2002. Principal component analysis.2Th edition.Springer: New York.

[12] Pratama RI, Sumaryanto H, Santoso J dan Zahirudin W. 2012. Karakteristik Sensori Beberapa Produk Ikan Asap Khas Daerah di Indonesia dengan Menggunakan Metode Quantitative Descriptive Analysis. IPB Perikanan Vol. 7 No.2 Tahun 2012:117-130.

[13] J. J. Piggott and K. Sherman. "Methods to aid interpredation of multivariate data," In: J. R. Piggott, Ed., Statistical procedures in food research, Elsevier applied science, London, 1986.

[14] Ramasamy Ravi, Vivek Kumar Singh, Maya Prakash]. 2011 Food and Nutrition Sciences, 2011, 2, 674-683 doi:10.4236/fns.2011.26093. Projective Mapping and Product Positioning of Deep Fat Fried Snack

[15] Kemp, Hollowood dan Hort. 2009). Sensory Evaluation A practical handbook. Wiley-Blackwell. United Kingdom. 211p.

[16] Lund, M. N. dan Ray, C. A. 2017. Control of Maillard Reactions in Foods: Strategies and Chemical Mechanisms. J. Agric. Food Chem., 65 (23), pp 4537-4552.

[17] Oliveira F.C.D, Coimbra J.S.D.R,Oliveira E.B.D, Zuniga A.D.G, Rojas E.E.G. 2014. Food Protein-Polysaccharide Conjugates obtained via the Maillard Reaction: A Review. Crit. Rev. Food Sci Nutr.13:37-41.

[18] Winarno, F.G. 2004. Kimia Pangan dan Gizi. Jakarta : Gramedia Pustaka Utama.

[19] Antara, N. S. Dan Wartini, M. 2011. Senyawa Aroma dan Cita Rasa. Report of Tropical Plant Curiculum Project. Texas A \& M University-Udayana University.

[20] Purba, M. 2014. Pembentukan Flavor Daging Unggas oleh Proses Pemanasan dan Oksidasi Lipida. WARTAZOA Vol. 24 No. 3. Hal. $109-118$.

[21] Sartono, B., F. M. Affendi, U. D. Syafitri, I. M. Sumertajaya, dan Y.Anggraeni. 2003. Analisis Peubah Ganda. FMIPA IPB, Bogor. $317 \mathrm{p}$. 